\title{
Partial dolomitization of foreslope and toe-of-slope facies of a Carnian carbonate platform, Transdanubian Range, Hungary
}

\author{
János Haas' ${ }^{1}$, Tamás Budai ${ }^{2}$, Attila Demény ${ }^{3}$ \\ ${ }^{1}$ MTA-ELTE Geological, Geophysical and Space Science Research Group, Budapest, Hungary \\ ${ }^{2}$ Geological and Geophysical Institute, Budapest, Hungary \\ ${ }^{3}$ Research Centre for Astronomy and Earth Sciences, Hungarian Academy of Sciences, Budapest, Hungary
}

\begin{abstract}
Partial and pervasive dolomitization of foreslope and toe-of-slope deposits of an early Carnian carbonate platform was investigated to understand the process and mechanism of dolomitization. Based on petrographic observations and $\mathrm{C}$ and $\mathrm{O}$ isotope data, the dolomitization took place in a nearsurface to shallow burial setting; seawater of slightly elevated salinity was likely the dolomitizing fluid. The circulation system was maintained by reflux of evaporated sea water and geothermal heating of cold seawater derived from the surrounding deeper basin. The dolomitization was mostly controlled by the permeability of the platform-derived calcareous sediments.
\end{abstract}

Key words: Triassic, slope deposits, dolomitization, stable isotopes

\section{Introduction}

In the Middle Triassic, in connection with western Neotethys rifting, an extensional tectonic regime was established, which led to the development of carbonate platforms and basins in the area of the Transdanubian Range (Budai and Vörös 1992). In the Late Anisian a predominant part of the area of the Balaton Highland became a relatively deep basin, while a large carbonate platform came into existence in the northeastern part of the Transdanubian Range, and a submarine slope was formed between them (Haas and Budai 1999; Haas et al. 2000). During the transgressional periods the basin environment extended over a large part of the slope, while deceleration and cessation of the sea-level rise resulted in the progradation of the neighboring platform. In the course of the long-lasting platform evolution, an approximately $1 \mathrm{~km}$-thick platform carbonate succession was accumulated, which was affected by pervasive dolomitization. In contrast, the coeval basin and slope facies were not or only slightly affected by dolomitization. This situation provides a good opportunity for the study of the dolomitization processes.

\footnotetext{
Addresses: J. Haas: H-1117 Budapest, Pázmány P. sétány 1/c, Hungary; e-mail: haas@caesar.elte.hu T. Budai: H-1143 Budapest, Stefánia út 14, Hungary A. Demény: H-1112 Budapest, Budaörsi út 45, Hungary

Received: October 9, 2013; accepted: February 1, 2014
} 
East of Veszprém, a small abandoned quarry exposes a prograding slope succession between Late Ladinian basinal and Early Carnian platform carbonate beds. The lower part of the several meter-thick carbonate turbidite succession, punctuated by clayey interbeds, is practically non-dolomitized, whereas the topmost part of this interval is partially dolomitized. The upper part of the succession is pervasively dolomitized. Stratigraphic and sedimentological investigation of the section was performed earlier (Szabó 1990; Haas et al. 2000). The aim of the present work is the petrographic and geochemical investigation of the dolomitization of this section. The conclusions of this study may also have consequences for the interpretation of the dolomitization of the coeval platform carbonates.

\section{Geologic setting}

In the northeastern part of the Transdanubian Range, from the Buda Hills to the Veszprém Plateau and in the South Bakony, the Ladinian to Lower Carnian succession is made up of platform carbonates. On the Balaton Highland this stratigraphic interval is represented by basin facies. Interfingering of platform and basin facies is recognized, and slope and toe-of-slope facies are observed near Veszprém in the western part of the Veszprém Plateau (Haas and Budai 1999) (Figs 1 and 2). Surface exposures of this transitional facies belt (paleoslope) are known in road-cuts of Highway No. 8 and in quarries in the surroundings of Hajmáskér (Fig. 3); the entire succession is excellently exposed in core Hmt-3 (Fig. 4).

In the Hajmáskér-Sóly area (Fig. 3) the Middle Anisian is represented by Pelsonian dolomitized platform carbonates rich in dasycladalean algae (Physoporella pauciforata, Oligoporella) (Tagyon Formation) that is directly overlain by Upper Illyrian tuffitic crinoidal limestone (Vászoly Formation), with a rich

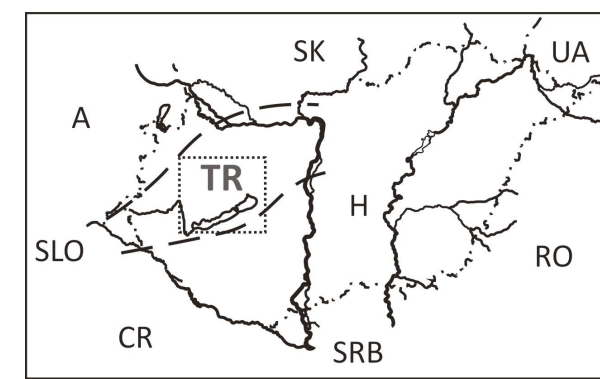

Fig. 1

Simplified map of surface extension of the Triassic formations in the Bakony Mountains showing the position of the geologic map of the Hajmáskér-Sóly area (Fig. 3)

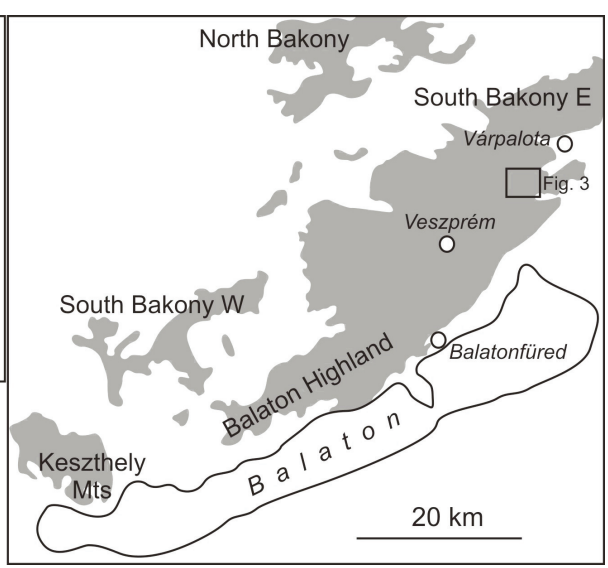


ammonite assemblage of the Avisianum Subzone of the Reitzi Zone (Vörös 1998; Budai et al. 2001; Budai 2006).

These Upper Illyrian basinal layers are overlain by the first prograding wedge of the coeval Budaörs Platform (Fig. 2). This thick-bedded dolomite, which contains lithoclasts and plasticlasts, can be interpreted as proximal slope facies (Budai and Vörös 2006). It is overlain by a Ladinian basin succession, which is made up of red or grey nodular siliceous and cherty limestone with marl and volcanic tuff intercalations (Buchenstein Formation). In the road-cuts of Highway No. 8 thin-shelled bivalves (Daonella) and ammonites were found in the limestone assigned to the Upper Ladinian Gredleri and Archelaus Zones (Vörös 1998; Budai et al. 2001; Budai 2006).

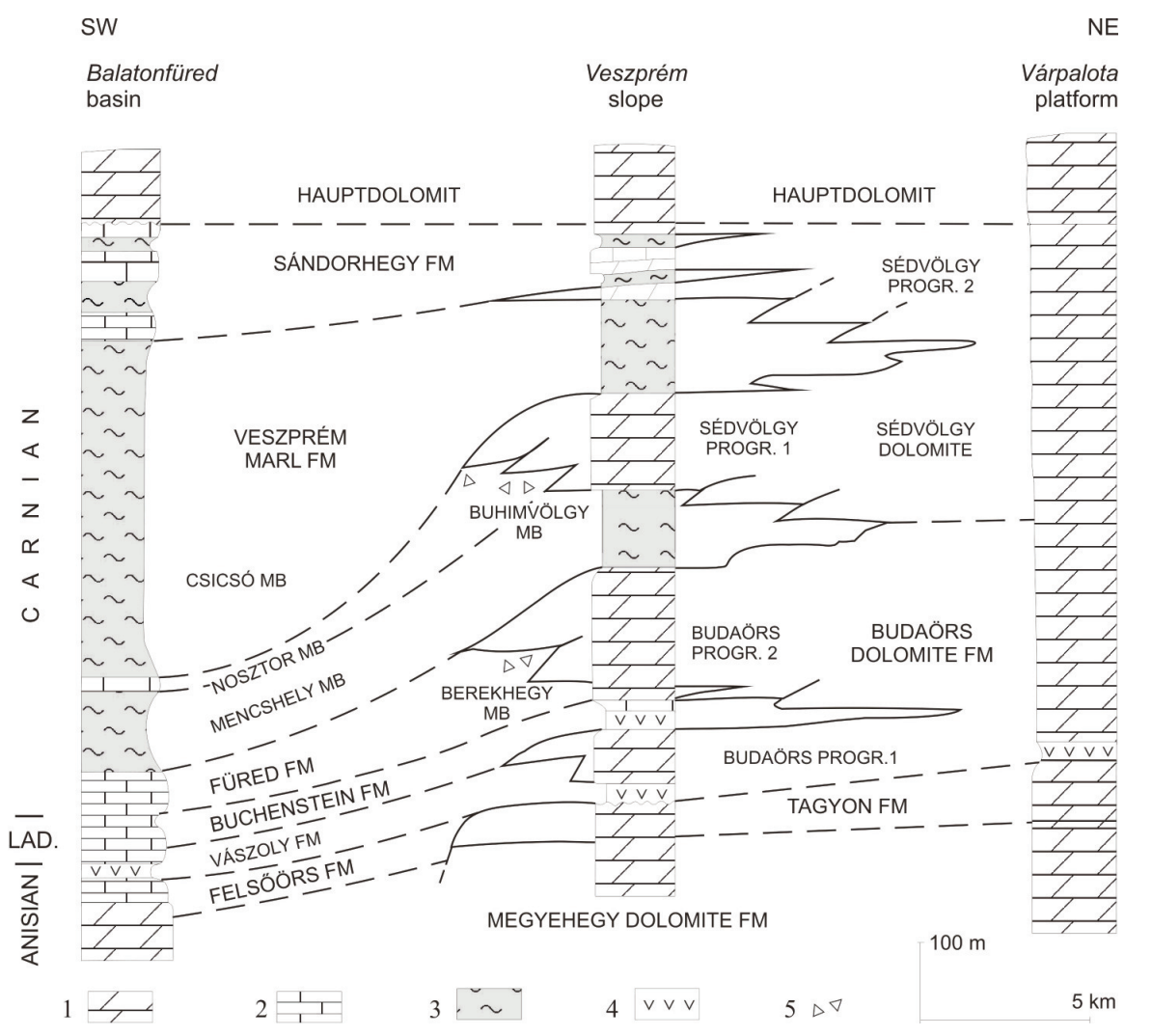

Fig. 2

Schematic cross-section of the Middle-Upper Triassic platform and basin succession along the Veszprém Plateau and the Balaton Highland (after Haas and Budai 1999). 1. platform carbonates; 2. basinal carbonates; 3 . basinal marls; 4 . volcanites; 5 . redeposited clasts of platform origin 


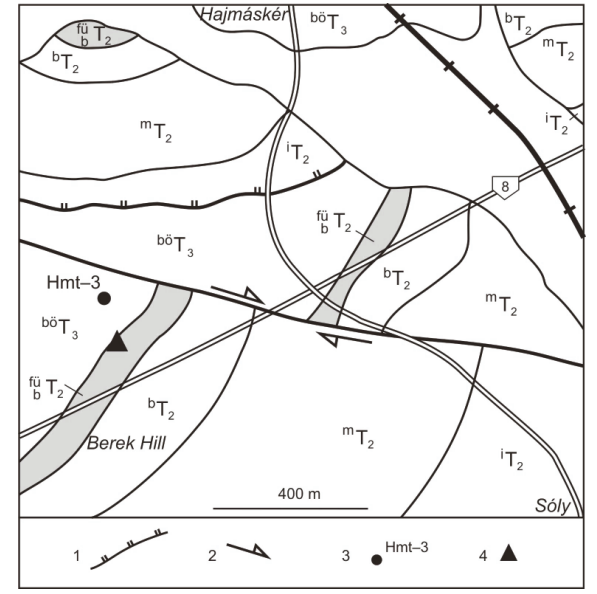

Fig. 3

Simplified geologic map of the Hajmáskér-Sóly area (after Haas et al. 2000); iT2 - Iszkahegy Limestone (Lower Anisian); $\mathrm{m}_{2}-$ Megyehegy and Tagyon Formations (Middle Anisian); ${ }^{\mathrm{b}} \mathrm{T}_{2}-$ Vászoly and Buchenstein Formations (Upper Anisian-Ladinian); $\quad$ fü $_{\mathrm{bT}_{2}} \quad$ - Berekhegy Limestone (uppermost Ladinian); bö $_{3}-$ Budaörs Dolomite (Lower Carnian). 1. Veszprém overthrust; 2 . strike-slip fault; 3 . borehole; 4. location of the Hajmáskér Quarry (geologic section in Fig. 5) succession can be interpreted as the record of the second prograding phase of the Budaörs Platform, with clinoforms dipping towards the coeval Balatonfüred Basin (Fig. 2).

\section{Methodology}

For re-evaluation of the microfacies, the data of our previous bed-by-bed microscopic investigation were applied (Haas et al. 2000). We also used $\mathrm{CaO}$ and $\mathrm{MgO}$ analytical data of the Hungarian Institute of Geology (1997) determined using a solution of equal parts $\mathrm{HCl}$ and water. The former sampling was supplemented by detailed microscopic study of three newly collected samples from beds 22, 38 and 54. Alizarin red-S and potassium ferricyanide stains were used to determine the carbonate phases in these samples (Dickson 1966).

Carbon and oxygen isotope compositions of bulk sediment carbonate (Beds 34, $35,42,45$ and 53) were determined using the conventional $\mathrm{H}_{3} \mathrm{PO}_{4}$ digestion method at $25{ }^{\circ} \mathrm{C}$ (McCrea 1950), with reaction times of about 15 hours and 48 hours for calcite and dolomite, respectively (Al-Aasm et al. 1990). Calcite-acid and 
dolomite-acid fractionation factors given by Al-Aasm et al. (1990) were used. The ${ }^{13} \mathrm{C} /{ }^{12} \mathrm{C}$ and ${ }^{18} \mathrm{O} /{ }^{16} \mathrm{O}$ ratios of $\mathrm{CO}_{2}$ generated were measured with a Finnigan MAT delta $S$ mass spectrometer. Batches of $0.1-0.2 \mathrm{mg}$ of carbonates from layers
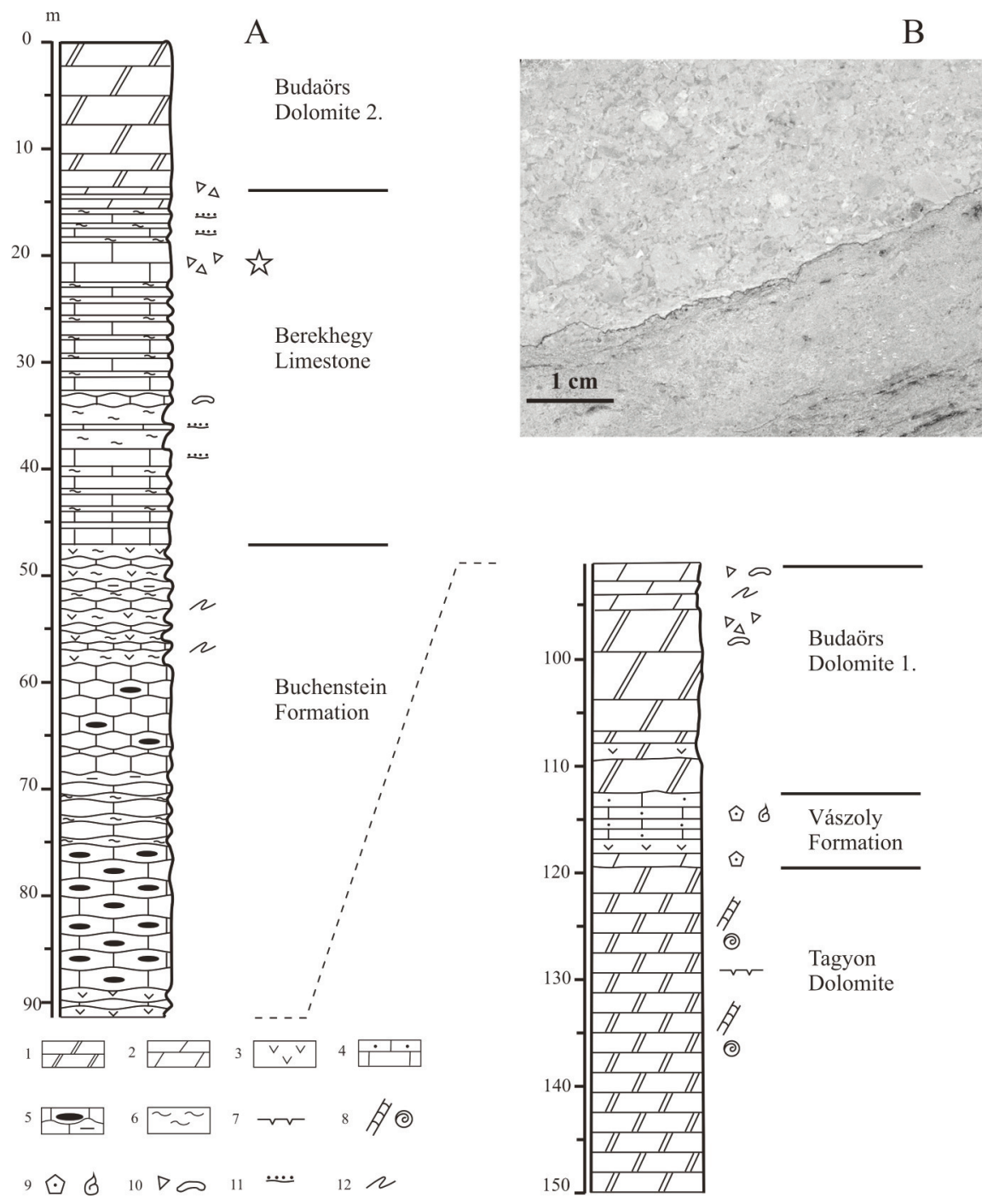

Fig. 4

Stratigraphic column of core Hmt-3 (A); polished slab of the Berekhegy Limestone showing graded stratification of platform-derived clasts (B) (after Budai 2006). Position of the sample is marked by an asterisk beside the column. 1. platform dolomite; 2 . dolomitized limestone; 3 . tuff, tuffite; 4 . crinoidal limestone; 5 . nodular cherty limestone of basin facies; 6. marl; 7. mud-cracks; 8 . dasycladalean algae, oncoids; 9. crinoid ossicles, ammonoids; 10. lithoclasts, plasticlasts; 11. graded bedding; 12 . slump 
22, 38 and 54 were analyzed using an automated GASBENCH device attached to a Finnigan Thermo delta plus XP mass spectrometer (see Spötl and Vennemann 2003). Standardization was conducted using laboratory calcite and dolomite standards calibrated against the NBS-19 standard. The results are expressed in the $\delta$-notation in \%o relative $\mathrm{V}$-PDB $\left[\delta=\left(\mathrm{R}_{1} / \mathrm{R}_{2}-1\right) \times 1000\right]$ where $\mathrm{R}_{1}$ is the ${ }^{13} \mathrm{C} /{ }^{12} \mathrm{C}$ or ${ }^{18} \mathrm{O} /{ }^{16} \mathrm{O}$ ratio in the sample and $\mathrm{R}_{2}$ the corresponding ratio of the standard. Reproducibilities for both $\mathrm{C}$ and $\mathrm{O}$ isotope analyses were better than $\pm 0.15 \%$.

\section{Summary of petrographic characteristic of the succession}

An approximately 6 m-thick succession of the Berekhegy Limestone Member was investigated in the Hajmáskér Quarry (Figs 5 and 6). Basic lithofacies characteristics of the sequence are presented in Fig. 7. The lower $3 \mathrm{~m}$ of the succession is brownish grey thin-bedded limestone whereas the upper $3 \mathrm{~m}$ thick interval consists of thin and thicker beds of light grey dolomite (Fig. 8).

The limestone interval is made up of 10-15 cm-thick layers which are separated by uneven erosional bedding surfaces (Fig. 9A). The basal part of the limestone layers commonly contains $\mathrm{mm}$ to $\mathrm{cm}$-sized lithoclasts and coarse calcarenite (Fig. 10). Normal grading is typical within the strata; above the basal coarse-grained grainstone interval, finer-grained grainstone or wackestone occurs and clayey wackestone appears at the topmost part of the layers (Fig. 11A, B).

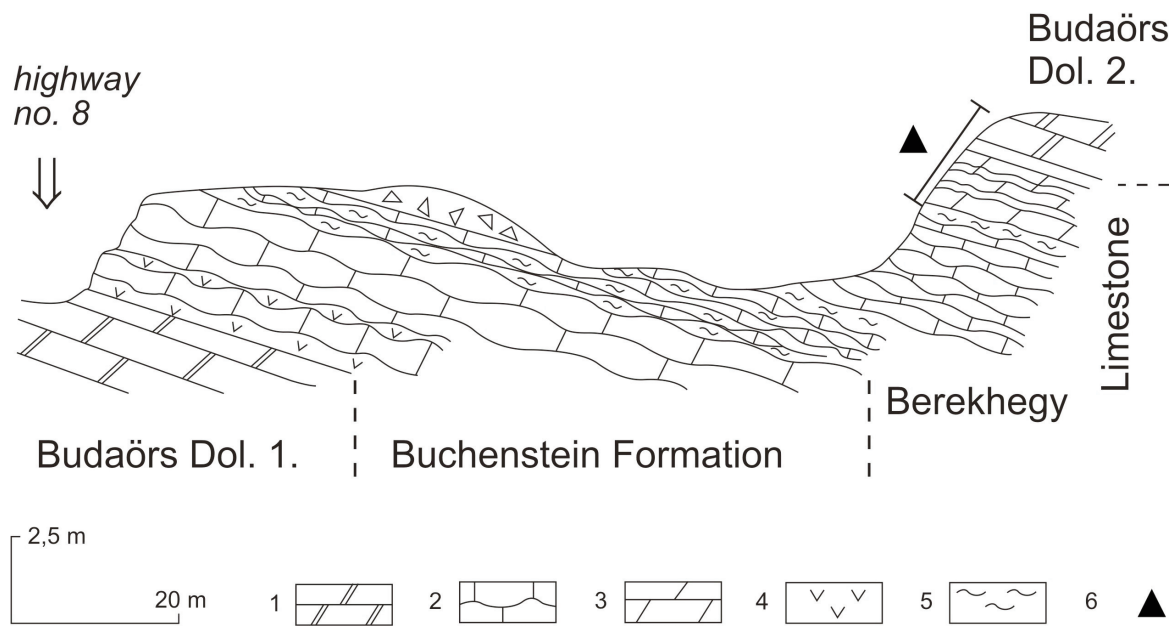

Fig. 5

Geologic section of the Berekhegy Quarry at Hajmáskér (after Szabó 1990 and Haas et al. 2000), showing the position of the studied section in Figs 5 and 6. 1. platform dolomite; 2. nodular limestone of basin facies; 3. dolomitized limestone; 4. tuff, tuffite; 5 . marl; 6. position of the studied section 


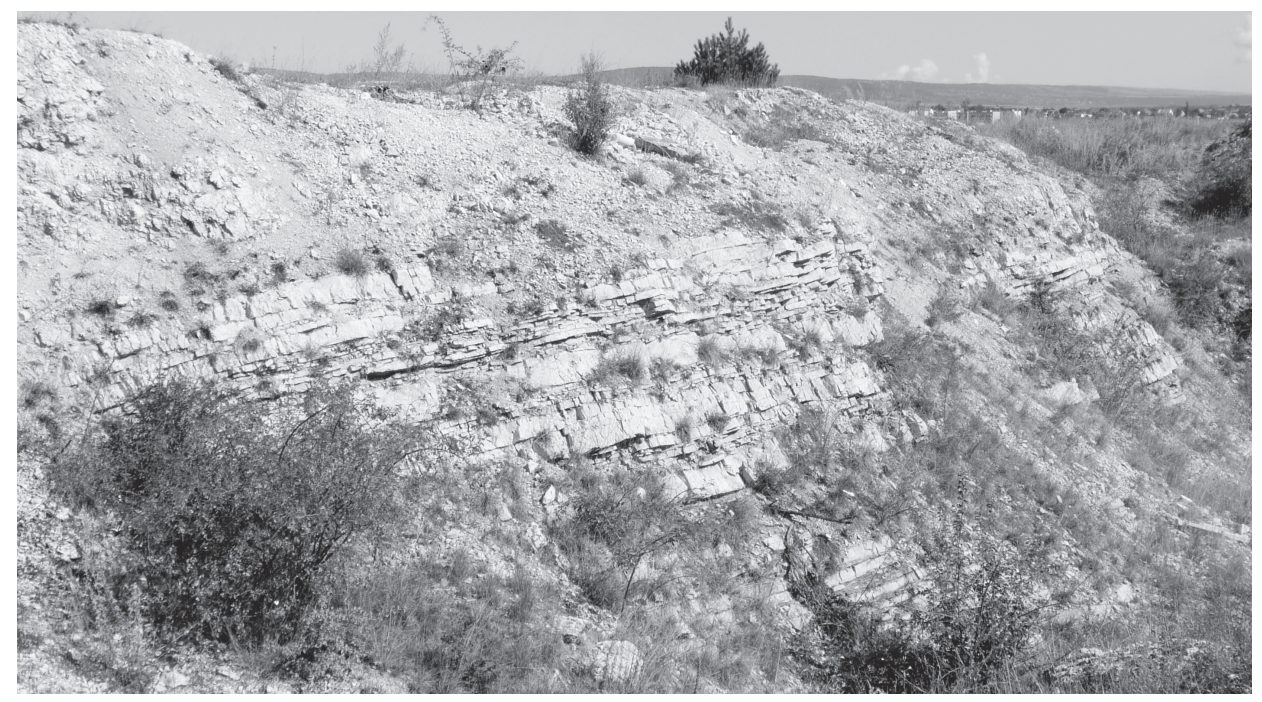

Fig. 6

The studied succession in the Hajmáskér Quarry. The well-bedded limestone-dolomite sequence is overlain by thick bedded to massive dolomite, i.e. the 2 nd progradation tongue of the Budaörs Dolomite

In the coarse-grained grainstone, the platform-derived lithoclasts containing fragments of calcareous sponges, encrusting foraminifera and microbial crusts are predominant (Fig 11C). Among the bioclasts fragments of echinoderms, green algae, calcareous sponges, mollusks, and "microproblematica" (Koivanella permiensis, Ladinella porata, Panormidella aggregate, Tubiphytes carinthiacus, T. obscurus) are the most characteristic (Haas et al. 2000). In the finer-grained grainstone or wackestone smaller lithoclasts may also occur; fragments of echinoderms, mollusks, ostracodes, foraminifera and Tubiphytes are common. Sponge spicules and thin-shelled bivalves may also appear, but rarely. In the clayey wackestone fragments of thin-shelled bivalves are common and molds of radiolarians may also be present in small quantity.

The lowermost, nearly $2 \mathrm{~m}$-thick part of the section is practically free of any dolomitization. The upper one meter of the limestone interval was affected by low-grade (1-5\%), selective dolomitization. The dolomite appears in two forms. There are mm-sized irregular yellow dolomite patches which consist of microsparitic to finely crystalline $(10-50 \mu \mathrm{m})$ non-planar dolomite (Fig. 11D, E); similar dolomite occurs along stylolites and as fracture fill. In the central part of larger (mm-sized) pores, coarsely crystalline $(300-500 \mu \mathrm{m})$ planar-s dolomite occurs (Fig. 11D, E, F).

The limestone succession is separated from the pervasively dolomitized interval by a $10 \mathrm{~cm}$-thick marl horizon. Above it, in the lower part of the dolomite succession (Beds 35-48; Fig. 9B), the dolomitization destroyed the original depositional texture as a rule, although relic texture elements can be recognized 
$\mathrm{CaO} / \mathrm{MgO}$

$\delta^{13} \mathrm{C} \%$

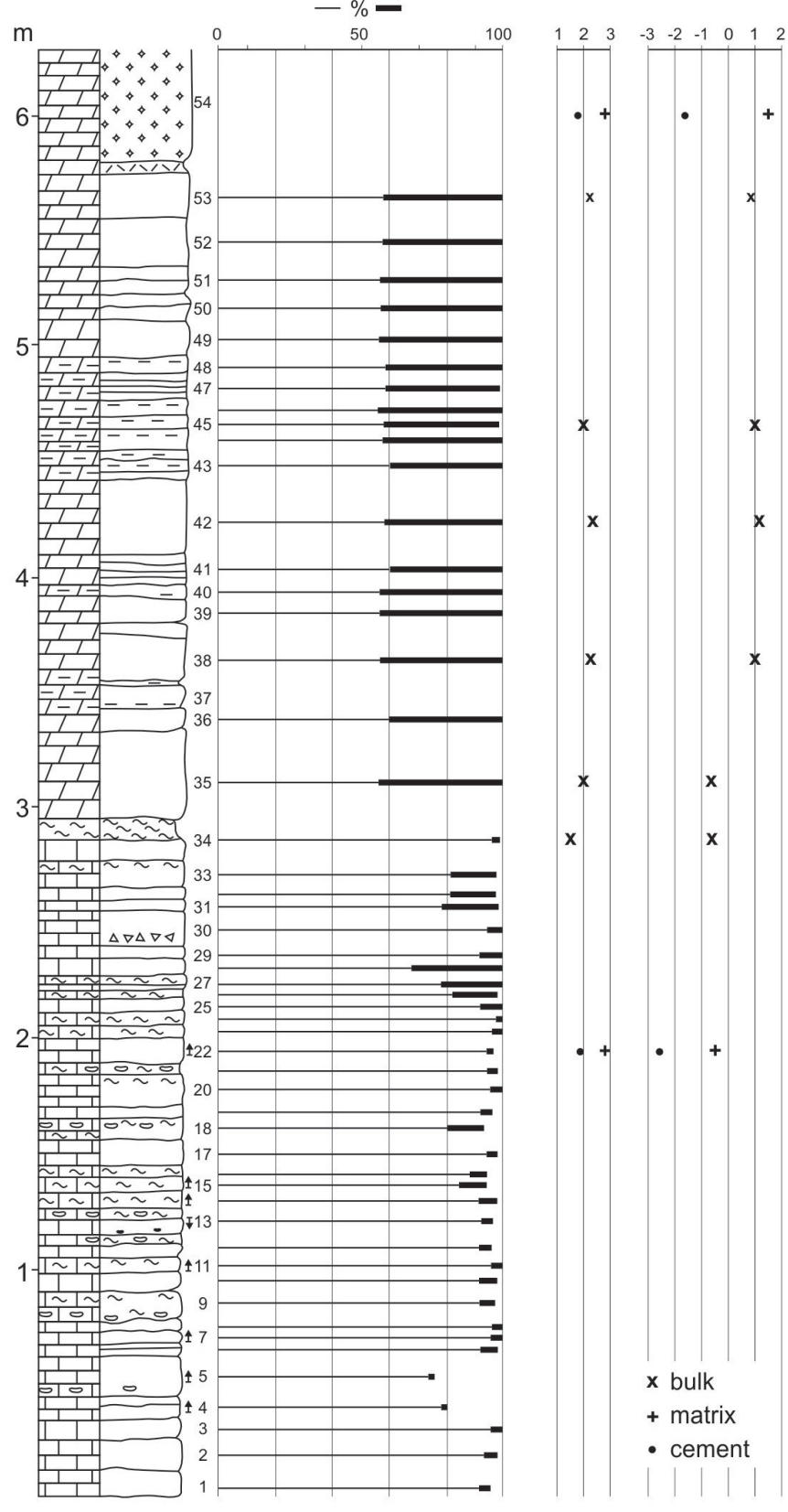

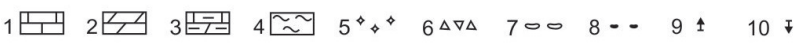

Central European Geology 57, 2014 


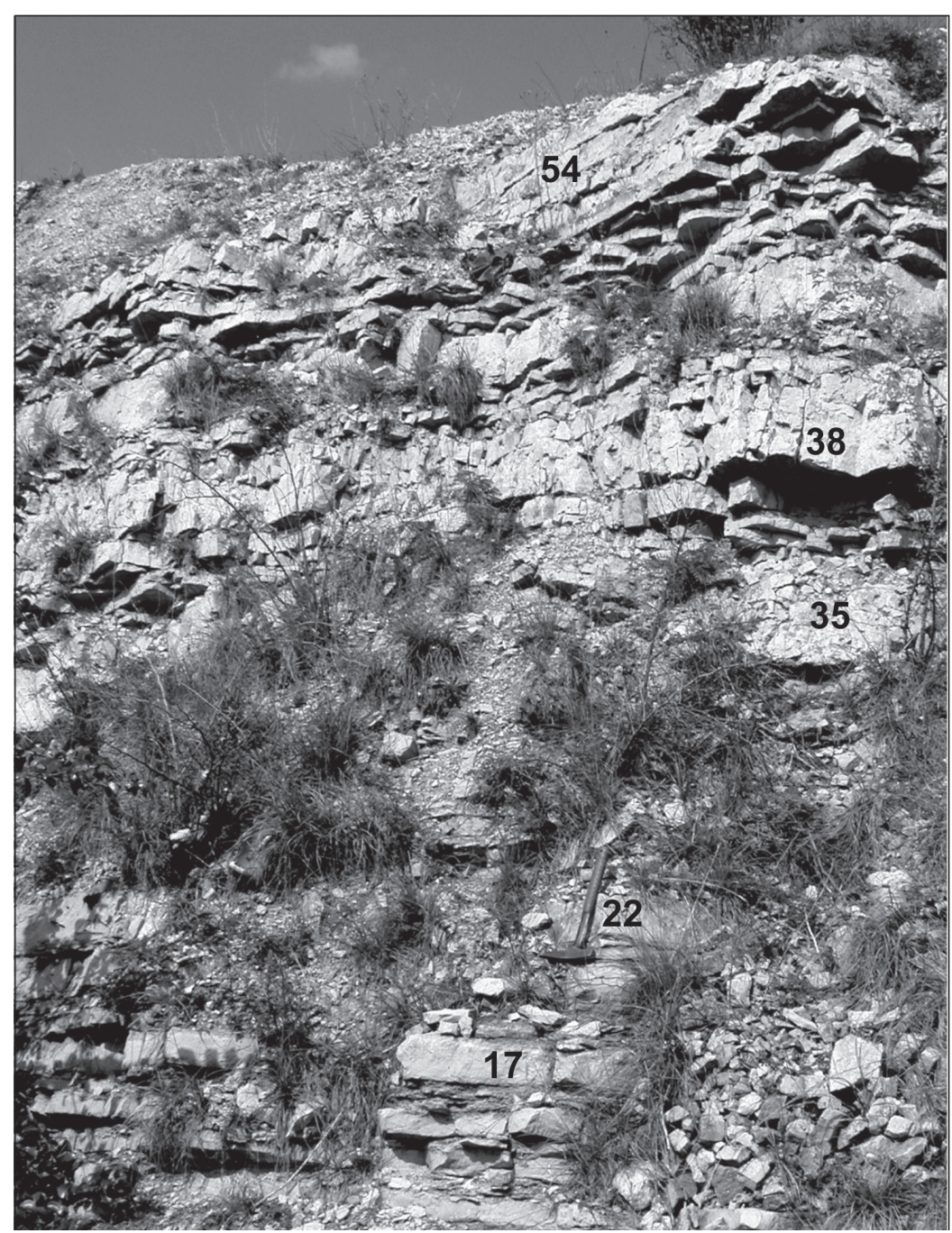

Fig. 8

Characteristic structure and general lithological features of the studied succession. The numbers mark those beds which were subjected to detailed investigation

$\leftarrow$ Fig. 7

Lithological column of the studied section, $\mathrm{CaO} / \mathrm{MgO}$ content, and $\mathrm{C}$ and $\mathrm{O}$ values of the measured samples (after Haas et al. 2000). 1. limestone; 2. dolomite; 3. argillaceous limestone/dolomite; 4. marl; 5. pores; 6 . lithoclasts; 7. carbonate nodules; 8 . chert nodules; 9 . normal grading; 10 . reverse grading 

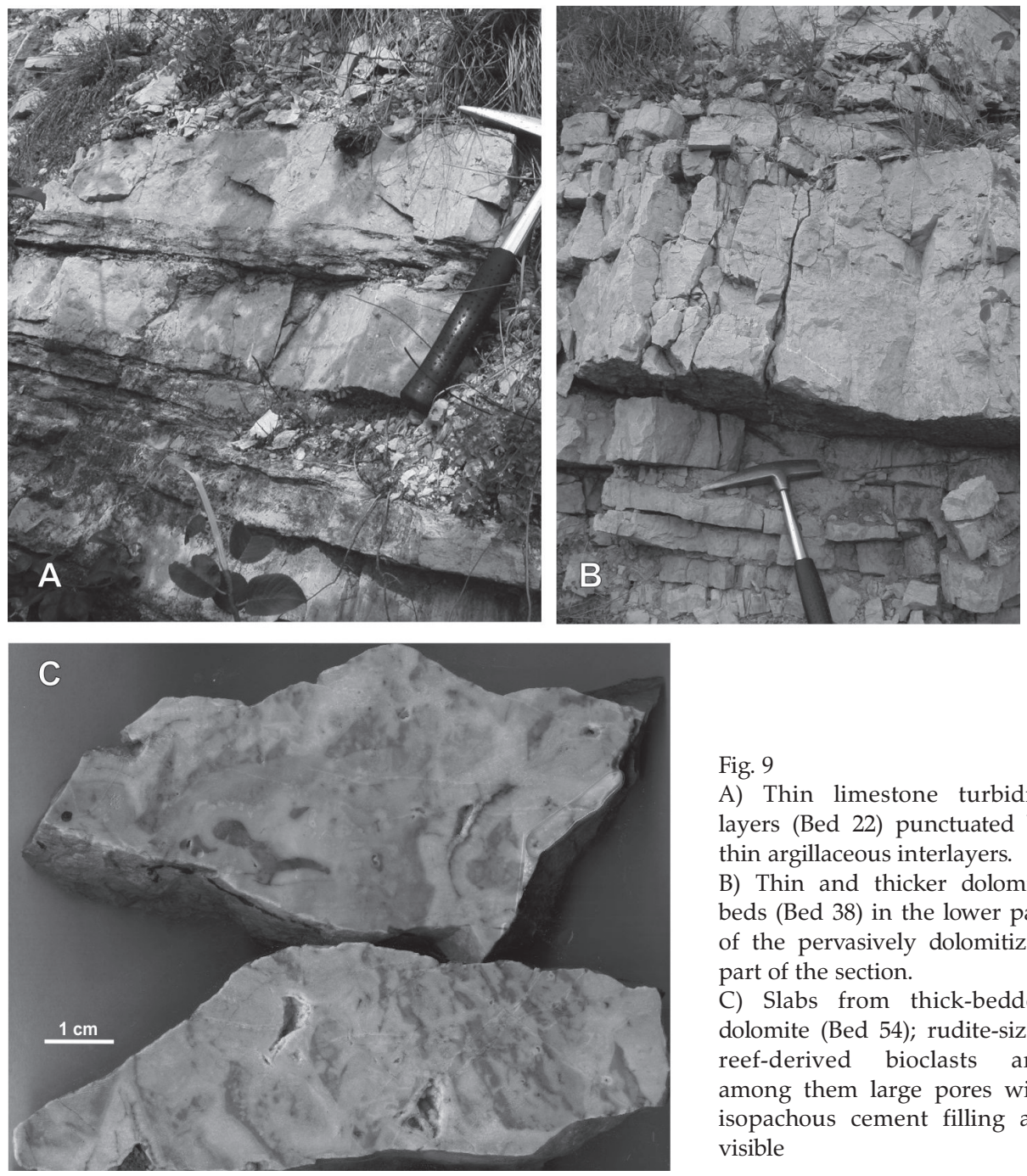

Fig. 9

A) Thin limestone turbidite layers (Bed 22) punctuated by thin argillaceous interlayers.

B) Thin and thicker dolomite beds (Bed 38) in the lower part of the pervasively dolomitized part of the section.

C) Slabs from thick-bedded dolomite (Bed 54); rudite-sized reef-derived bioclasts and among them large pores with isopachous cement filling are visible

in some beds (Fig. 12A). The characteristic texture consists mostly of very finely to finely crystalline planar-e or planar-s dolomite, usually with a brownish cloudy core. The relic elements are ghosts of bioclasts; probably remnants of micritic envelopes or micritized skeletons which are preserved as inclusion-rich patches in the recrystallized matrix.

In the upper part of the pervasively dolomitized interval the original sedimentary texture is better preserved and in several cases even the microfacies types, defined on the basis of the study of the limestone segment could be recognized. 


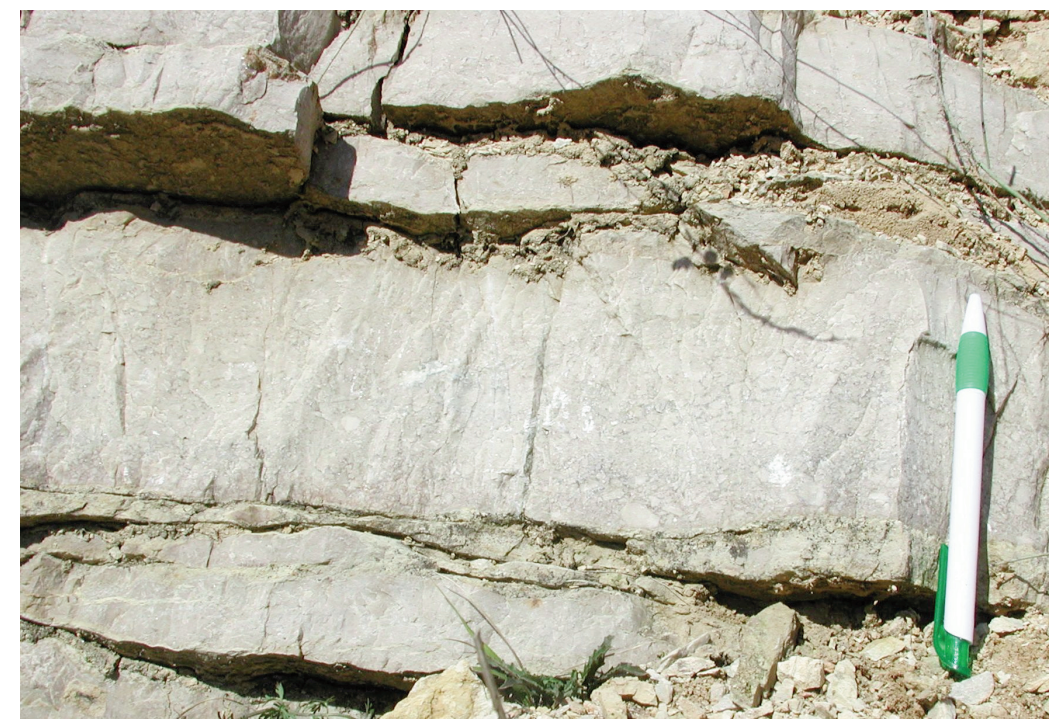

Fig. 10

Graded carbonate turbidite layers from the lower part of the section. Gravel-sized lithoclasts and coarse sand-sized lithoclasts and bioclasts are visible at the base of the layers above the uneven erosional boundary surfaces. The graded calcarenite intervals are overlain by calcisilt and calcilutite horizons which grade upward into argillaceous limestone to marl horizons

Fragments of calcareous sponges, echinoderms, mollusks, and a few foraminifera were found.

The thin-bedded succession is overlain by thicker dolomite beds (Bed 54; Fig. 9C). In spite of the usually fabric-destructive dolomitization, ghosts of $\mathrm{mm}$ to $\mathrm{cm}$ sized bioclasts (calcareous sponges?) and between them fibrous cement could be recognized (Fig. 12B).

\section{Stable isotopes}

Bulk dolomite samples have $\mathrm{C}$ and $\mathrm{O}$ isotope compositions of $+2.3 \pm 0.3 \%$ and $+0.7 \pm 0.6 \%$, respectively, whereas the sample from Bed 34 that contains no dolomite had a calcite composition of $\delta^{13} \mathrm{C}=+1.6 \%$ and $\delta^{18} \mathrm{O}=-0.8 \%$. The coarsely-crystalline dolomite cement of Bed 22 and the fibrous dolomite cement of Bed 54 have significantly lower oxygen isotope values $(-2.5$ and $-1.6 \%$, respectively) but similar carbon isotope compositions $(+1.8 \%$ for both) compared to the bulk dolomitic rocks.

Beside the above-mentioned differences, systematic changes in $\delta^{13} \mathrm{C}$ and $\delta^{18} \mathrm{O}$ values can also be detected up-section (Figs 7, 13). Selecting the samples with $\delta^{18} \mathrm{O}>0 \%$ (least affected by diagenetic alteration), the $\mathrm{C}$ and $\mathrm{O}$ isotope compositions show a positive correlation (slope $=0.86, \mathrm{R} 2=0.78$ ), indicating that evaporation affected the $\mathrm{C}$ and $\mathrm{O}$ isotope compositions. The relatively steep 

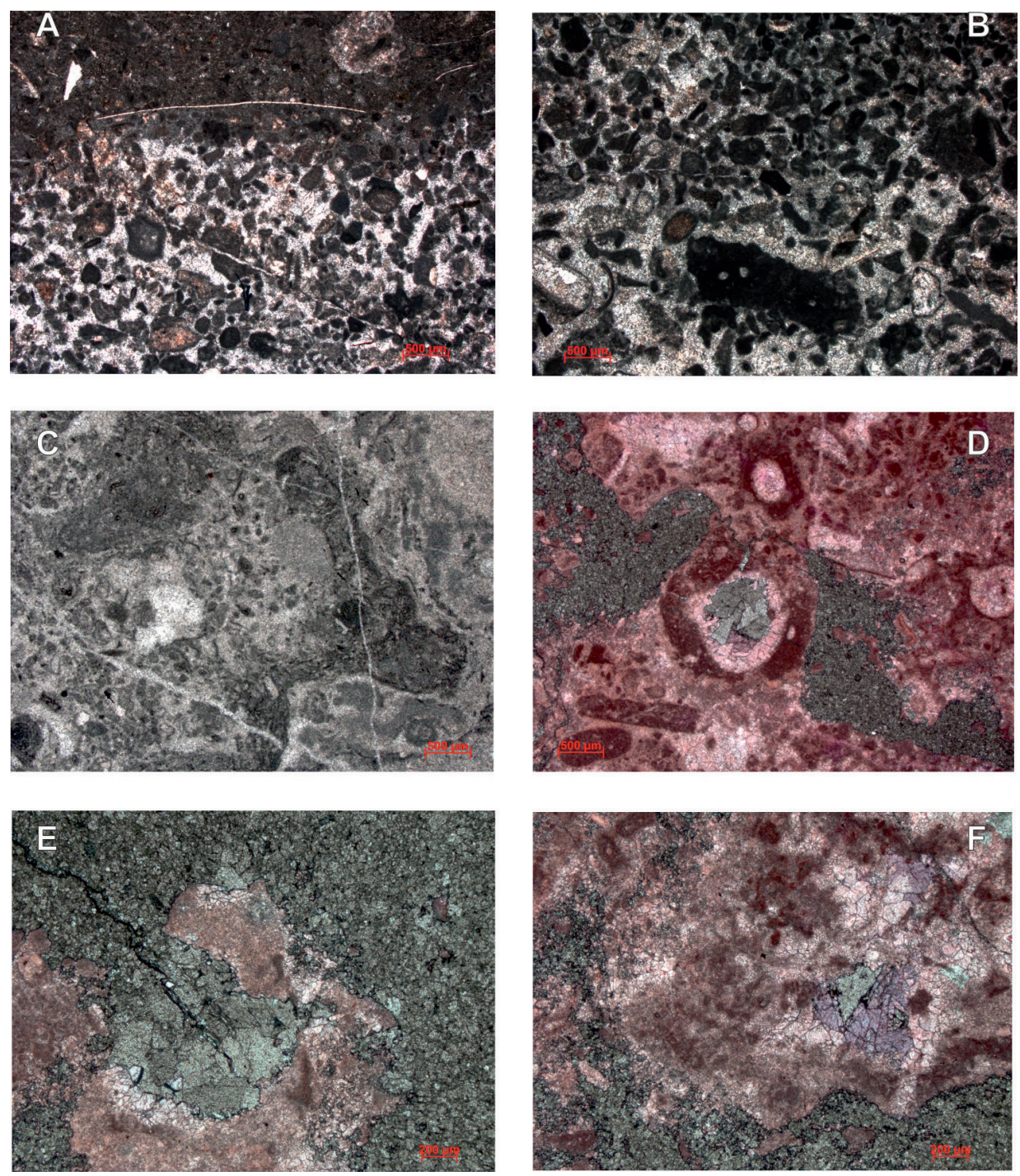

Fig. 11

Microfacies characteristics of limestone turbidite layers. In the stained thin sections the pink color indicates calcite, dolomite is unstained, and ferroan calcite has a turquoise-bluish color. A) Lithoclastic, peloidal, bioclastic grainstone; upward-fining calcerenite (stained thin section). B) The grainstone is overlain by peloidal packstone-wackestone containing fragments of thin-shelled bivalves. C) Microbially encrusted composite grain containing intraclasts, peloids and microbial nodules in microsparitic matrix (stained thin section); Bed 22. D), E) Partial dolomitization of the limestone. Replacive microsparitic to finely crystalline dolomite occur in mm-sized patches, whereas coarsely crystalline dolomite cement is visible in a secondary pore formed by partial dissolution of the previous calcite cement (stained thin section); Bed 22. F) Partial dedolomitization of coarsely crystalline dolomite cement leading to formation of ferroan calcite (stained thin section); Bed 22 

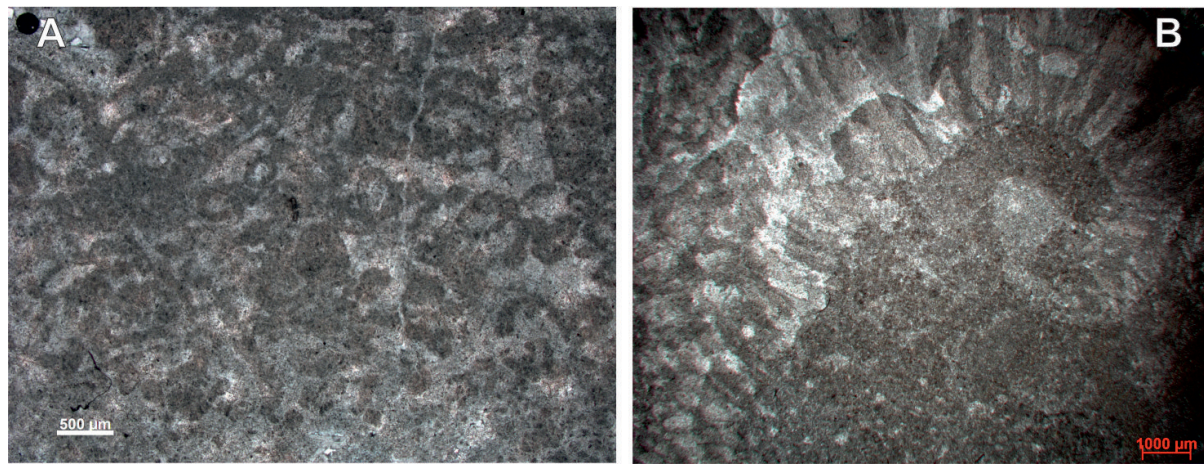

Fig. 12

A) Relic texture elements (ghosts of bioclasts, peloids) in finely crystalline dolomite; (Bed 38)

B) Dolomitized fibrous cement among of ghosts of $\mathrm{mm}$ to $\mathrm{cm}$-sized reef-derived bioclasts (Bed 54)

$\delta^{13} \mathrm{C}-\delta^{18} \mathrm{O}$ slope suggests seawater evaporation under semi-humid conditions as proposed by Haas and Demény (2002). The up-section increase in the $\delta^{13} \mathrm{C}$ and $\delta^{18} \mathrm{O}$ values can be attributed to i) increasing efficiency of evaporation on the top of the platform, or ii) a change in the mixing ratio between the refluxing evaporated seawater derived from the platform surface and upward circulating normal-salinity seawater derived from the deeper part of the basin and infiltrated through the platform slope.

The samples taken from limestone beds (Beds 22 and 34) have lower $\mathrm{O}$ isotope compositions in accordance with the theoretical calcite-dolomite difference. The slightly lower $\delta^{18} \mathrm{O}$ and unchanged $\delta^{13} \mathrm{C}$ values of coarselycrystalline dolomite cement (Bed 22) and dolomitized fibrous cement (Bed 54) can be related to dolomitizing fluids of ultimately seawater origin that migrated at only slightly elevated temperature.

Comparing the isotopic compositions with data from the Upper

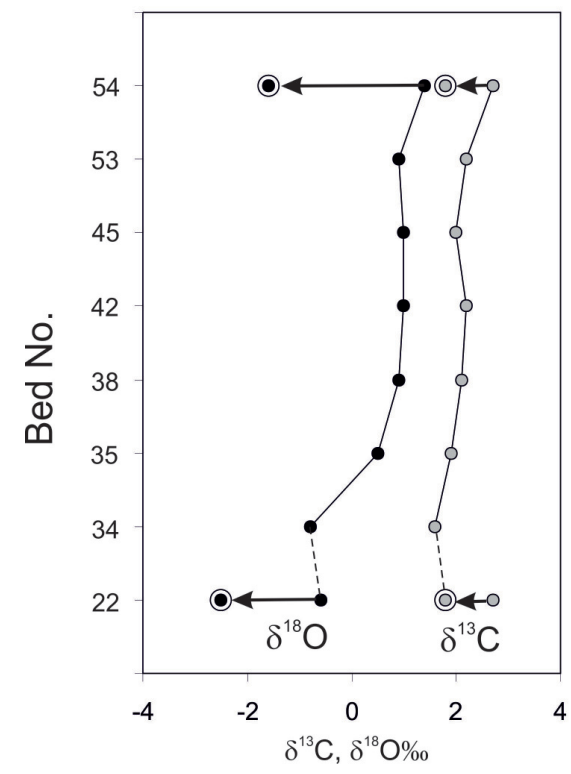

Fig. 13

Changes of $\delta^{13} \mathrm{C}$ and $\delta^{18} \mathrm{O}$ values (in $\%$ relative to $\mathrm{V}-\mathrm{PDB}$ ) in the studied succession. Large empty circles mark cement samples; arrows indicate the directions of isotopic shifts in the cement relative to the dolomite in the same samples 
Triassic, Hauptdolomit and partially dolomitized limestone representing the transition between the Hauptdolomit and the Dachstein Limestone Formations in the northeastern part of the Transdanubian Range (Haas and Demény 2002) it is apparent that the dolomite compositions obtained in this study do not reach the field of the Hauptdolomit, which was formed under a semi-arid climate, but the oxygen isotope values are higher than those of the transitional succession (Epöl and Kablás sections in the Gerecse Mts), which was developed under semi-humid conditions (Fig. 14).

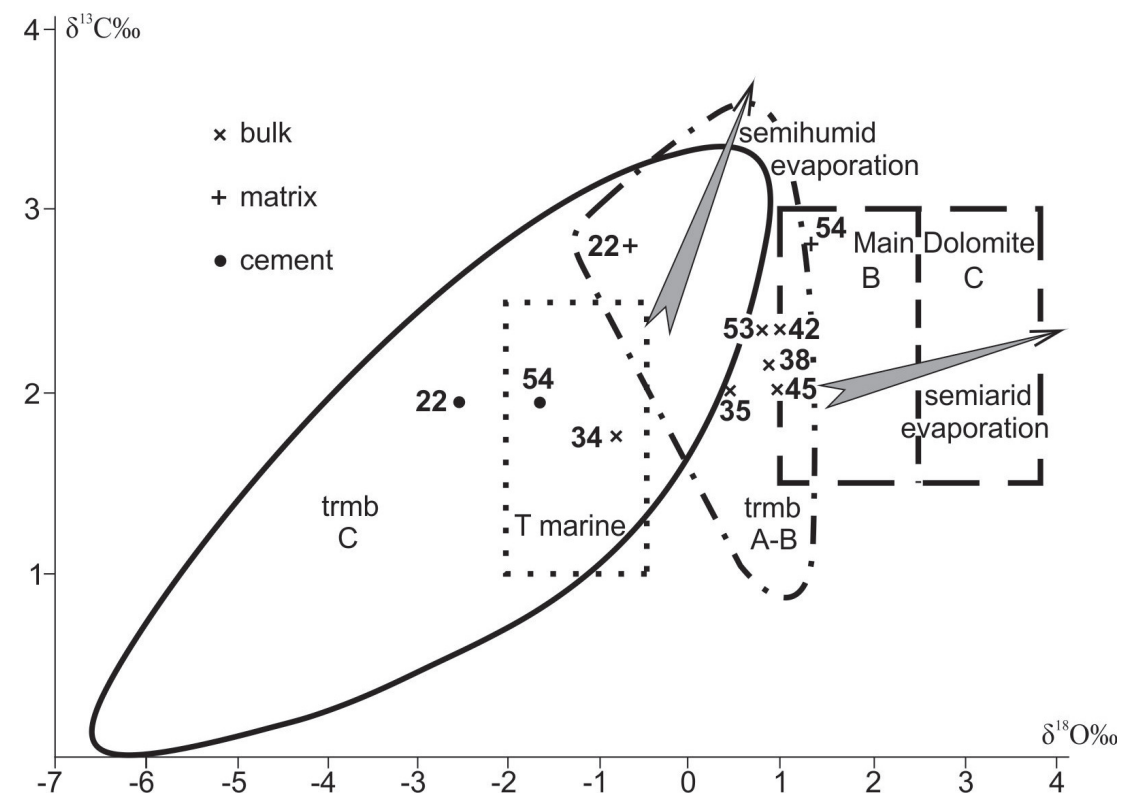

Fig. 14

Comparison of the isotopic compositions (see Fig. 13) of the studied section of the Berekhegy Member with those obtained for Upper Triassic, Hauptdolomit and partially dolomitized limestone representing the transition between the Hauptdolomit and the Dachstein Limestone Formations in the northeastern part of the Transdanubian Range (Haas and Demény 2002). T marine - Triassic marine calcite; trmb - transitional unit between the Hauptdolomit and the Dachstein Limestone; A A facies of the Lofer cycles; B - B facies of the Lofer cycles; C - C facies of the Lofer cycles

\section{Discussion}

The grey nodular, locally silicified limestone with pelagic fossils (radiolarians, ammonites) in the basal part of the exposed section can be interpreted as a hemipelagic basin facies. The overlying succession (Berekhegy Limestone Member) is made up of bedded carbonates punctuated by uneven bedding 
plains. In the lower, thin-bedded limestone interval, the erosional base of the beds and the commonly observed normal gradation indicate deposition via turbidity currents. The presence of platform and upper slope-derived lithoclasts and bioclasts implies a platform margin source area. Pelagic fossil elements (thinshelled bivalves, radiolarians) in wackestone and occasionally in thin clayey interbeds suggest hemipelagic basinal deposition between the turbiditic events. The thin-bedded limestone turbidite succession may have been formed at the toeof-slope in the proximal to distal part of the slope apron. The thicker beds of the lower part of the pervasively dolomitized interval probably represent a lower slope depositional setting whereas the mostly thin-bedded upper part of the dolomitized segment may have been deposited in the toe-of-slope belt. The thick beds of the topmost part of the exposed succession can be interpreted as a platform foreslope facies. The whole succession can be interpreted as the record of a prograding platform foreslope (Fig. 15).

The redeposited bioclasts and lithoclasts provide information on the nature of the neighboring carbonate platform. At the platform margin the encrusting organism ("microproblematica") may have created wave resistant reef-like structures. Fragments of these biostructures are predominant in the turbidite beds. However, tubiphytes that are common constituents of reefs and that may form smaller reef-like structures on slopes (Flügel 2004), and fragments of crinoids that probably thrived mostly on the slope terraces, are also common in the turbidites, and bioclasts of internal platform origin (e.g. green algae, foraminifera) are also present. In the limestone beds neither the lithoclasts nor the bioclasts were affected by dolomitization. This means that calcareous grains and lime mud were transported from the platform to the slope and the basin prior to the pervasive dolomitization of the contemporaneous neighboring platform

$\begin{array}{lll}\text { basin } & \begin{array}{l}\text { toe-of- } \\ \text { slope foreslope }\end{array}\end{array}$

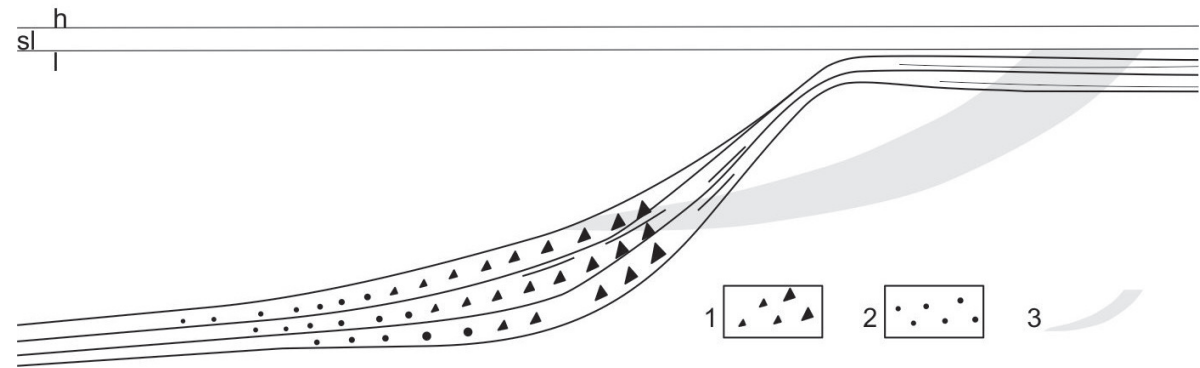

Fig. 15

Sedimentation model for the 2nd platform progradation of the Budaörs platform in the study area. Reflux of slightly evaporated sea-water which probably contributed to the dolomitization of studied succession is also displayed. Legend: 1 . rudstone fore-reef facies; 2 . carbonate turbidite toe-of-slope facies; 3. reflux of evaporated sea-water 
carbonates, which are completely dolomitized at present. Consequently dolomitization commenced subsequent to the sediment deposition, in the course of burial.

According to the stable $\mathrm{C}$ and $\mathrm{O}$ isotope data, sea-water, probably of slightly elevated salinity, may have been the dolomitizing agent that caused pervasive dolomitization of the upper part of the succession and may have played a significant role in the pervasive dolomitization of the overlying platform carbonates (Budaörs Dolomite Formation), as well. For pervasive dolomitization of large carbonate bodies active circulation is needed. Comprehensive studies of the Great Bahamas Bank provided the best examples for large-scale circulation of saline water in platform carbonates. The circulation comprises saline water input both from the platform surface and from the surrounding oceanic basins, and is driven by various flow mechanisms involving differences in salinity and water temperature and position of the sea-level (Wihtaker and Smart 1993). Studies performed in the area of the Great Bahamas Bank (Melim et al. 2001) and other Neogene to Quaternary isolated carbonate platforms which have never been deeply buried (Budd 1997; Jones and Luth 2003; Choquette and Hiatt 2007) revealed the importance of the dolomitization processes by marine pore fluids during the early burial stage. In the cores drilled on the western margin of the Great Bahamas Bank various amounts of dolomite of various textural types were encountered in the Quaternary to Late Neogene succession. According to studies of Melim et al. (2001) shallow burial diagenesis in marine pore fluids shows different patterns depending on the original sediment type and related permeability. Early compaction and sealing of peloidal grainstone to packstone largely protected them from subsequent diagenesis and led to more closedsystem diagenesis (blocky spar cementation, neomorphism of aragonitic grains, recrystallization of mud to micrite, microsparite). The more permeable intervals are characterized by aragonite dissolution and dolomitization. In the most permeable parts of reef and slope facies pervasive dolomitization was encountered in the Neogene succession of the Great Bahamas Bank.

Considering the above-discussed examples of shallow burial dolomitization, pervasive dolomitization of the upper part of the studied section may have taken place under similar conditions, i.e. in a shallow burial setting, probably via reflux of evaporated seawater derived from the surface of the internal platform that mixed with normal-salinity seawater transported by slope-related open-cell thermal convection (Fig. 16).

Turbidite layers with grainstone to wackestone texture and punctuated by thin argillaceous horizons which make up the lower part of the succession were less permeable then the overlying thicker bed-set where the clayey interbeds are missing. The difference in sediment permeability and in the early compaction may have caused the basic difference in the dolomitization potential of the lower and upper part of the succession. Based on petrographic observations microcrystalline to finely crystalline dolomite insertions and fracture fills in the 


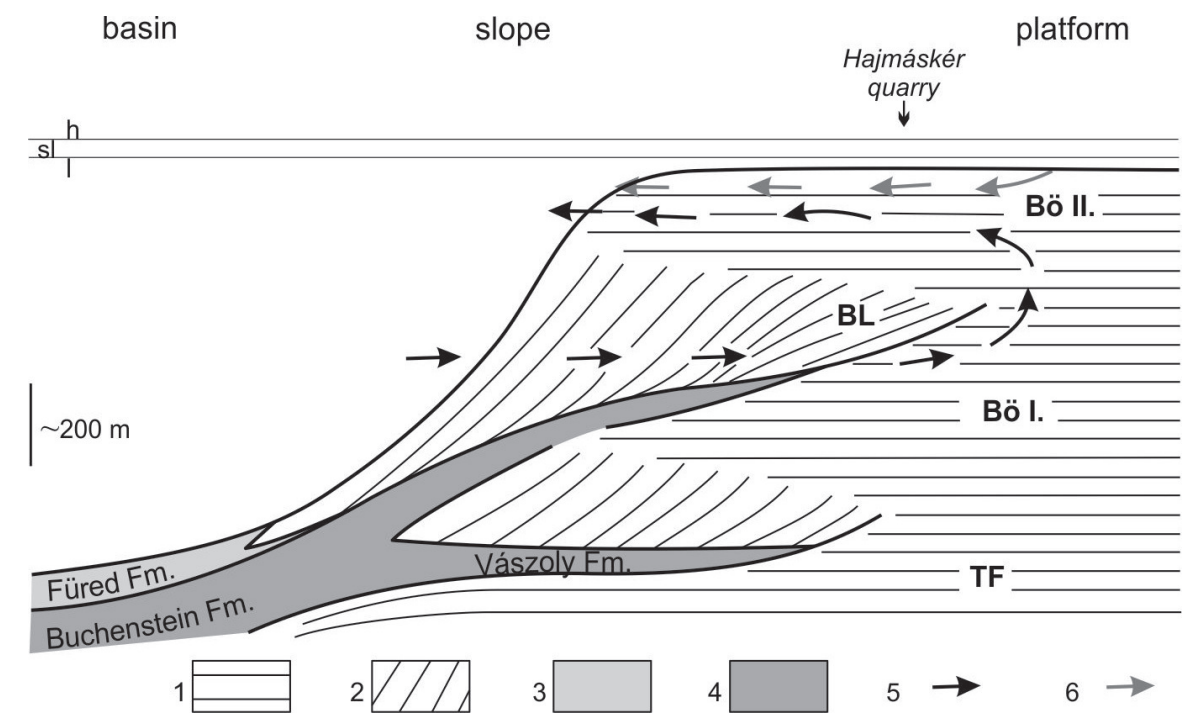

Fig. 16

Depositional and shallow burial circulation model for the Ladinian to Early Carnian period. 1. platform carbonates; 2. slope, and toe-of-slope deposits; margin; 3. Late Ladinian to Early Carnian basin facies; 4 . Ladinian basin facies; 5 . thermally-driven slope-related circulation; 6. reflux. BL Berekhegy Limestone; Bö I and Bö II - progradations of the Budaörs platform; TF - Tagyon Formation

upper part of the limestone interval may have occurred later but probably still in the shallow burial zone. It was followed by the precipitation of the coarsely crystalline dolomite cement in some pores in a shallow to intermediate burial setting.

\section{Conclusions}

1. On the basis of field observations and microfacies investigations the studied section of the Hajmáskér Quarry provides a thin but continuous record of a prograding slope from basin deposits through toe-of-slope to platform foreslope sediments.

2. The basin deposits, which are characterized by silicified wackestone texture, and the carbonate turbidite beds of toe-of-slope facies, which consist of graded beds with coarse sand to silt-sized grains and are punctuated by clayey interbeds, are non-dolomitized or contain only small amounts of dolomite in the form of finely-crystalline patches and/or pore and fracture-filling cement. The higher part of the succession, which comprises mostly coarser-grained foreslope deposits (bioclastic-lithoclastic rudstone) and does not contain clayey interbeds, is pervasively dolomitized. There is a sharp boundary between the limestone and the dolomite lithology and a $10 \mathrm{~cm}$-thick marl horizon occurs between them. 
3. Based on the $\mathrm{C}$ and $\mathrm{O}$ isotope data, dolomitization of the succession took place in a near surface to shallow burial setting. Relatively cold seawater of slightly elevated salinity may have acted as the dolomitizing fluid. Reflux of evaporated sea water derived from the tidal flat during low sea-level periods and slope-related thermal circulation during shallow burial may have contributed to the formation of dolomitizing fluid, with the mixing ratio of the two components changing through time.

4. Dolomitization of the semi-consolidated platform-derived calcareous sediments may have been mostly controlled by the permeability. Pervasive dolomitization was encountered in the originally highly permeable proximal platform foreslope and reef-slope deposits.

\section{Acknowledgements}

This work was supported by the Hungarian National Science Fund (OTKA) grant K 81296. The authors are grateful to Nereo Preto (Padova University) and to Roman Aubrecht (Comenius University, Bratislava) for the careful review of the manuscript.

\section{References}

Al-Aasm, I.S., B.E. Taylor, B. South. 1990: Stable isotope analysis of multiple carbonate samples using selective acid extraction. - Chemical Geology, 80, pp. 119-125.

Budai, T. 1993: Füredi Mészkő Formáció (Füred Limestone Formation). - In: Haas, J. (Ed.): Magyarország litosztratigráfiai alapegységei. Triász (Lithostratigraphic Units of Hungary. Triassic). Magyar Állami Földtani Intézet, pp. 56-59.

Budai, T. 2006: Medencék és platformok kialakulása és fejlódése a Bakony középsô triász története során (Development and evolution of basins and platforms during the Middle Triassic of the Bakony Mts). - Kézirat, akadémiai doktori értekezés (Manuscript) Országos Földtani Szakkönyvtár

Budai, T., A. Vörös 1992: Middle Triassic history of the Balaton Highland: extensional tectonics and basin evolution. - Acta Geologica Hungarica, 35/3, pp. 237-250.

Budai, T., A. Vörös 2006: Middle Triassic platform and basin evolution of the Southern Bakony Mountains (Transdanubian Range, Hungary). - Rivista Italiana Paleontologica Stratigrafia, 112/3, pp. 359-371.

Budai, T., G. Csillag, A. Vörös, L. Dosztály 2001: Középső- és késő-triász platform- és medencefáciesek a Veszprémi-fennsíkon (Middle to Late Triassic platform and basin facies of the Veszprém plateau, Transdanubian Range, Hungary). - Földtani Közlöny, 131/1-2, pp. 37-70.

Budd, D.A. 1997: Cenozoic dolomites of carbonate islands: their attributes and origin. - Earth-Sci. Rev., 42, pp. 1-47.

Choquette, Ph.W., E.E. Hiatt 2008: Shallow-burial dolomite cement: a major component of many ancient sucrosic dolomites. - Sedimentology, 55, pp. 423-460.

Dickson, J.A.D. 1966: Carbonate identification and genesis as revealed by staining. - J. Sed. Petrol., 36, pp. 491-505.

Flügel, E. 2004: Microfacies of carbonate rocks. - Springer. 976 p.

Haas, J., T. Budai 1999: Triassic sequence stratigraphy of the Transdanubian Range, Hungary. Geologica Carpathica, 50/6, pp. 459-475. 
Haas, J., T. Budai, L. Dosztály, A. Oravecz-Scheffer, E. Tardy-Filácz 2000: A "Budaörsi platform" (felsőladin-alsó-karni) előtéri lejtőfáciese Veszprém környékén. A Berekhegyi Mészkő hajmáskéri alapszelvényének vizsgálata (Upper Ladinian-Lower Carnian platform-slope facies in the Veszprém area, Transdanubian Range, Hungary). - Földtani Közlöny, 130/4, pp. 725-758.

Haas, J., A. Demény 2002: Early dolomitization of Late Triassic platform carbonates in the Transdanubian Range (Hungary). - Sedimentary Geology, 151, pp. 225-242.

Jones, B., R.W. Luth 2003: Temporal evolution of Tertiary dolostones on Grand Cayman as determined by ${ }^{87} \mathrm{Sr} /{ }^{86} \mathrm{Sr}$. - Journal Sedimentary Research, 73, pp. 187-205.

Laczkó, D. 1911: Veszprém városának és tágabb környékének geológiai leírása - A Balaton tudományos tanulmányozásának eredményei (Die geologischen Verhältnisse von Veszprém und seiner weiteren Umgebung - In: Resultate der wissenschaftlichen Erforschung des Balatonsees 1 (1) Geologischer, petrographischer, mineralogischer und mineralchemischer Anhang (1), pp. 1-207). (In Hungarian with German abstract.)

McCrea, J.M. 1950: On the isotope chemistry of carbonates and a paleotemperature scale. - The Journal of Chemical Physics, 18, pp. 849-857.

Melim, L.E., P.S. Swart, R.G. Maliva 2001: Meteoric and marine-burial diagenesis in the subsurface of Great Bahamas bank. - In: Ginsburg R.N. (Ed.): Subsurface Geology of a Prograding Carbonate Platform margin, Great Bahamas Bank: Results of the Bahamas Drilling Project. SEPM Spec. Publ., 70, pp. 137-161.

Spötl, C., T.W. Vennemann 2003: Continuous-flow isotope ratio mass spectrometric analysis of carbonate minerals. - Rapid Communications in Mass Spectrometry, 17, pp. 1004-1006.

Szabó, I. 1990: Bakony, Hajmáskér, Berekhegyi mészkő kőfejtője (Berekhegyi Mészkő Formáció) ((Bakony, Hajmáskér, Berekhegy limestone quarry (Berekhegy Limestone Formation)). Magyarország geológiai alapszelvényei - Geological key-sections of Hungary, MÁFI, Budapest, $5 \mathrm{p}$.

Vörös, A. 1998: A Balaton-felvidék triász ammonoideái és biosztratigráfiája (Triassic ammonoids and biostratigraphy of the Balaton Highland). - Studia Naturalia, 12, 105 p.

Whitaker, F.F, P.L. Smart 1993: Circulation of saline groundwaters in carbonate platforms: a review and case study from the Bahamas. - In: Horbury, A.D., A.G. Robinson (Eds): Diagenesis and Basin Development. AAPG Studies in Geology, 36, pp. 113-132. 